\title{
Emblica officinalis (Amla) with a Particular Focus on Its Antimicrobial Potentials: A Review
}

\author{
Sandip Kumar Khurana ${ }^{1}$ D, Ruchi Tiwari ${ }^{2}$ D , Khan Sharun ${ }^{3}$ (D) Mohd. Iqbal \\ Yatoo $^{4}$ (D) Mudasir Bashir Gugjoo ${ }^{5}$ (D) and Kuldeep Dhama ${ }^{6 *}$ (D)
}

${ }^{1}$ ICAR-Central Institute for Research on Buffaloes, Hisar - 125 001, Haryana, India. ${ }^{2}$ Department of Veterinary Microbiology and Immunology, College of Veterinary Sciences, Deen Dayal Upadhayay Pashu Chikitsa Vigyan Vishwavidyalay Evum Go-Anusandhan Sansthan (DUVASU), Mathura, India - 281001 , India. ${ }^{3}$ Division of Surgery, ICAR-Indian Veterinary Research Institute, Izatnagar, Bareilly - 243 122, Uttar Pradesh, India. ${ }^{4}$ Sher-E-Kashmir University of Agricultural Sciences and Technology of Kashmir, Shalimar - 190025 Srinagar, Jammu and Kashmir, India. ${ }^{5}$ Division of Veterinary Clinical Complex, Faculty of Veterinary Sciences \& Animal Husbandry, Sher-E-Kashmir University of Agricultural Sciences and Technology of Kashmir, Shalimar - 190025 Srinagar, Jammu and Kashmir, India - 190 006. ' Division of Pathology, ICAR-Indian Veterinary Research Institute, Izatnagar, Bareilly - 243 122, Uttar Pradesh, India.

\begin{abstract}
Emblica officinalis Gaertn. or Phyllanthus emblica Linn., popularly called as Indian gooseberry or Amla, is among main herbal plant in Indian traditional medicine. Different parts of $E$. officinalis are beneficial for curing various ailments but the fruits especially show tremendous pharmacological and medicinal applications. Phytochemical analysis revealed important bioactive chemical compounds such as tannins, alkaloids, polyphenols, gallic acid, ellagic acid, emblicanin A and B, phyllembein, quercetin, ascorbic acids, vitamins and minerals. Different extracts of amla possess potent antimicrobial activities to counter different bacterial pathogens. Amla phytochemicals also possess antioxidant, anti-inflammatory, hepatoprotective, cardioprotective, immunomodulatory, hypolipedemic, memory enhancing, anticancer, antidiabetic, antidepressant, anti-ulcerogenic, insecticidal, larvicidal, and wound healing activities. All of these well-established activities can have broad applications in managing most of the diseases affecting human and animal patients. It can either replace the conventional therapeutic agents due to its superior efficacy and lack of side effects or can act an adjunct therapeutic agent thereby enhancing the total efficacy of conventional agents. The biogenic synthesis of nanoparticles from $E$. officinalis is getting popularity due to the low cost factor along with the enhanced antimicrobial activity of the nanoparticles produced. The current review emphasizes on the phytochemical constituents, mechanisms behind the antimicrobial activity and also briefly summarizes other medicinal and therapeutic usefulness of the $E$. officinalis.
\end{abstract}

Keywords: Emblica officinalis, Amla, Antimicrobial effects, Phytochemicals, Pharmacological activity, Therapeutic usefulness, Health.

*Correspondence: kdhama@rediffmail.com

(Received: 18 September 2019; accepted: 22 October 2019)

Citation: Sandip Kumar Khurana, Ruchi Tiwari, Khan Sharun, Mohd. Iqbal Yatoo, Mudasir Bashir Gugjoo and Kuldeep Dhama, Emblica officinalis (Amla) with a Particular Focus on its Antimicrobial potentials: A Review, J Pure App/ Microbiol., 2019; 13(4):19952012. https://doi.org/10.22207/JPAM.13.4.11

(C) The Author(s) 2019. Open Access. This article is distributed under the terms of the Creative Commons Attribution 4.0 International License which permits unrestricted use, sharing, distribution, and reproduction in any medium, provided you give appropriate credit to the original author(s) and the source, provide a link to the Creative Commons license, and indicate if changes were made. 


\section{INTRODUCTION}

Medicines of natural origin like herbs and plant metabolites / extracts are being used since long as beneficial remedies for managing and curing several diseases and disorders for protecting health of humans and animals ${ }^{1-6}$. Plants and herbs are a rich source of developing effective and alternative / complementary therapeutic drugs and medicines. Over the years several drugs have been developed that have made significant contributions to human health and wellbeing ${ }^{6,7}$. WHO has also approved the usage of herbal medicines for curing various diseases, from malaria to cancer ${ }^{8,9}$. Phyllanthus emblica syn. or Emblica officinalis (EO) (family Euphorbiaceae), also called 'Indian gooseberry' and 'Amla', is placed in category of most significant medicinal plants in traditional system of Indian medicine (Ayurveda) $)^{10-17}$. EO is a native herb of Indian tropical and subtropical regions, and is also found in Sri Lanka, Uzbekistan, South East Asia, and China nowadays ${ }^{18}$. EO possess vast beneficial health applications in traditional system such as liver tonic, diuretic, laxative, improving digestion, anti-pyretic, hair tonic, anti-ulcer, curing common cold and fever ${ }^{13,19-23}$. It also play role in enhancing memory, lowering cholesterol levels, neutralizing snake venom, curing infectious diseases and usage as a potent immunomodulator ${ }^{24}$.

The EO fruit contains high vitamin $C$ and other bioactive compounds such as polyphenols, ellagic acid, chebulinic acid, gallic acid, chebulagic acid, apeigenin, quercetin, corilagin, and leutolin ${ }^{11,15,16}$. Sugar-substituted phenolics (flavone, phenolic, flavonol glycosides) ${ }^{15}$, tannins (emblicanin A and B, phyllaemblicin B, punigluconoin) are present in fruit pulp $p^{16,25,26}$. Amla extracts have been extensively investigated for different biological activities ${ }^{15}$. These phytochemicals contribute to the antibacterial, antifungal, antiviral and other pharmacological activities ${ }^{27,28}$. Recent in vitro studies have revealed antiinflammatory ${ }^{29}$, antioxidant ${ }^{30,31}$, cytoprotective ${ }^{32}$, antiaging ${ }^{33}$, nephrotoxicity modulation $^{34}$, antidiabetic ${ }^{35}$ and hepatoprotective ${ }^{36}$ properties of amla. Some of the other applications includes anti-diarrheal, immunomodulator, gastroprotective, cardioprotective, analgesic, antipyretic, wound healing, antitussive, anti HIV-reverse transcriptase, insecticidal, larvicidal, antidepressant, neuroprotective, and radioprotective activity ${ }^{15,16,37}$. All of these actions are utilized for therapeutic purposes of conditions like tumors, cardio-respiratory disorders, diabetes, atherosclerosis, thrombotic events, osteoporosis, and neuropathy ${ }^{15}$. Antimicrobial resistance, a rising public health concern, need to be tackled with finding out alternative, complementary and novel therapeutic regimens $\mathrm{s}^{38,39}$. Medicinal herbs and plant extracts contain various bioactive constituents / phytochemicals having potent antimicrobial properties, while showing no toxic or adverse side effects ${ }^{3,19,40}$.

The present review highlights the antimicrobial potential, phytoconstituents and modes of action of Emblica officinalis and its extracts in humans and animals. Other pharmacological activities and beneficial health applications have also been discussed in brief.

\section{METHODS}

\section{Antimicrobial activities}

Several studies have been conducted to assess antimicrobial potential of different extracts of plants in the past decades. Most of the plant extracts evaluated were found to display significant antimicrobial action mostly due to several active constituents present in them ${ }^{3,6,7}$. Emblica officinalis has shown effective antimicrobial properties and usefulness for the designing effectual medicines ${ }^{13,16,21,22,24,37,41,42}$. The EO extracts posses antimicrobial properties like antifungal, antiviral and antibacterial activities ${ }^{17,28,43-46}$, and thus this plant is being explored for developing novel and alternative antibacterial and complementary treatment options in biomedical science owing to its potent medicinal values ${ }^{5,10,11,15,17,37,47,48-50}$.

\section{Antibacterial activity}

The antibacterial action of EO is higher for Gram-positive bacteria, while its effectiveness is limited for countering fungi ${ }^{51-53}$. The extracts of EO exhibited high zone of inhibition (ZOI) when tested for Escherichia coli, Klebsiella pneumoniae, Staphylcoccus aureus, Bacillus cereus, Vibrio cholerae and Candida albicans ${ }^{54}$. Antimicrobial effectiveness for Gram-positive, Gram-negative bacteria along with fungal agents reflects usage of fruit of $P$. emblica as a remedy for different microbial diseases ${ }^{50}$. 
The extracts of triphala and amla, obtained with aqueous and ethanolic solvents, showed antibacterial action for Pseudomonas aeruginosa, K. pneumoniae, Shigella sonnei, Shigella flexneri, S. aureus, V. cholerae, Salmonella paratyphi-B, E. coli, Enterococcus faecalis and Salmonella typhi ${ }^{55}$. Gallic and tannic acid, main phytoconstituents of EO, possess strong antimicrobial potential ${ }^{19}$. In vitro assessment of EO fruit and leaf showed 100 percent antibacterial, antiprotozoal and antifungal activities. In another study, EO demonstrated effective antibacterial action for E. coli, K. pneumoniae, K. ozaenae, P. mirabilis, $P$. aeruginosa, S. typhi, S. paratyphi A \& B, S. marcescens, while was not effective against few Gram-negative urinary pathogen $\mathrm{s}^{56}$. A long-term feeding (30 days) study in mice for finding protective effects of $P$. emblica against $K$. pneumoniae-induced pneumonia revealed that $P$. emblica supplementation reduced colonization of bacteria in the lungs ${ }^{57}$.

P. emblica and its extract possess antimicrobial and cytotoxic activities. The chloroform extract of $P$. emblica fruit revealed powerful inhibitory action for $B$. subtilis and moderate inhibition for $S$. typhi, Bacillus cereus, $P$. aeruginosa, Shigella boydii, Shigella dysenteriae, S. aureus, Sternbergia lutea, E. coli, S. paratyphi, Vibrio parahaemolyticus and Vibrio mimicus ${ }^{52}$. In vitro antibacterial action of EO fruit (ethanolic extracts) has been also reported against $V$. cholerae, S. aureus and $P$. aeruginosa isolates ${ }^{58}$. Aqueous extract of EO showed antibacterial effectiveness to inhibit $E$. coli, B. subtilis and $S$. aureus isolates ${ }^{59}$. Methanolic extracts of of $P$. emblica dried leaves showed antibacterial activity for two pathogenic bacteria, B. subtilis and $S$. aureus $^{60}$. EO aqueous fruit extracts revealed potent antibacterial effects for five human bacterial pathogen stock cultures, namely Bacillus sp., Lactobacillus sp., Pseudomonas sp., Proteus sp., Streptococcus species ${ }^{61}$. Different extracts of EO fruit tested against pathogens viz., E. coli, $S$. marcescens, $P$. aeruginosa and $B$. cereus, showed highest antibacterial action for E. coli by methanol extract followed by aqueous extract ${ }^{62}$.

The ethanolic extracts of henna, neem and amla revealed antimicrobial action against $E$. coli, while tulsi extract showed high antimicrobial action for Klebsiella63. Extracts of six medicinal plants revealed variable antimicrobial potential for oral pathogen S. mutans; crude extract of garlic showed high effectiveness (maximum zone of inhibition, ZOI) as compared to aqueous extract of amla and organic solvent of ginger ${ }^{24}$. The crude extracts of EO fruit in different solvents like hexane, chloroform and methanol revealed antibacterial activity against $E$. coli, K. pneumoniae, P. vulgaris, M. luteus, B. subtilis, E. faecalis and S. faecalis.. The hexane extract showed less antibacterial action as compared to the chloroform and methanol extracts $^{64}$.

Antimicrobial activity studied for different extracts of $P$. emblica revealed that the MIC exhibited by methanolic extract of amla against the tested organisms ranged between 0.2610.342 , this extract was found to have more antimicrobial property than chloroform and diethyl ether extracts ${ }^{65}$. Among $P$. emblica fruit extracts, highest ZOI for bacterial growth got obtained at $100 \mathrm{mg} / \mathrm{ml}$ at pH 8.0, followed by K. pneumoniae ATCC 31488 and S. aureus in ethanol solution extract ${ }^{66}$. Methanol extract of amla fruit has been found to be more potent for S. aureus, E. coli and K. pneumoniae as compared with methanolic leaf extract ${ }^{67}$. The crude extract of amla leaves showed highest inhibition for $E$. coli while lowest for $S$. typhis ${ }^{68}$. Acetone fruit extract was found to have maximal antibacterial action for E. coli, while methanol as well as aqueous extracts showed maximum activity for $S$. aureus and $K$. pneumonia, respectively ${ }^{19}$. Antimicrobial potential of EO methanolic seed extract has been reported against E. coli, P. aeruginosa, K. pneumoniae, S. aureus and Enterococcus clinical isolates, with maximum ZOI observed for $S$. aureus while to be lowest for P. aeruginosa $a^{42}$. Aqueous, ethanol and acetone extracts of EO fruits have been reported to have noteworthy antibacterial action for $S$. aureus as compared to $E$. coli ${ }^{69}$. The petroleum ether leaf extract of EO exhibited potent antibacterial and antifungal properties for all tested pathogenic strains in human except for $E_{\text {. }}$ faecalis $^{70}$.

P. emblica extract was observed to possess high antimicrobial effects for Grampositive, Gram-negative as well as resistant bacteria; the highest being observed against $B$. subtilis as indicated by the high ZOI $(25 \mathrm{~mm})$, while lowest against $S$. paratyphi, Pseudomonas spp., $S$. typhi as evident from the lower ZOI $(8 \mathrm{~mm})^{71}$. The 
aqueous extract gave the highest ZOI against $B$. subtilis followed by $E$. coli. The $5 \%$ aqueous extract of Amla has been reported to exhibit the highest ZOI, indicating potent antibacterial activity ${ }^{46}$. The potent antibacterial activity of EO against several microorganisms can be credited to tannins present in its fruits. Emblicanin A and B are the two major tannins that give antimicrobial property to the fruit extract of $E$. officinalis ${ }^{64}$. The tannins produce antimicrobial action due to the capability to inhibit microbial adhesions, inactivate enzymes, and cells envelop transport proteins ${ }^{72}$. Another compound Phyllemblin present in E. officinalis has significant antibacterial activity against several mastitis causing agents like S. pyogenes, S. aureus and $K$. pneumoniae $^{67,73}$.

Aqueous and methanolic extracts of EO fruits have well established antibacterial activity that varied among the Gram positive and negative groups of bacteria ${ }^{74}$. E. ofjicinalis is more effective against Gram-positive than Gram-negative bacteria, which may be due to differences in structure and composition of the cell wall62. A similar spectrum of activity was exhibited by phytofabricated selenium nanoparticles (PF-SeNPs) produced from EO fruit aqueous extract. The reduced antibacterial potential of PF-SeNPs for Gram negative bacteria may be due to strong electrostatic repulsion existing between PF-SeNPs and the Gram negative bacterial lipopolysaccharide which prevents their interaction ${ }^{75}$. Antimicrobial property of EO fruit extracts assessed for pathogens like $E$. coli, S. aureus and $S$. typhi ${ }^{28}$ revealed maximum activity for $S$. aureus by methanolic extract. The result suggests that the fruit extract produces maximum inhibition against Gram-positive rather than Gram-negative bacteria, again confirming superior antibacterial effectiveness of EO for Gram-positive bacteria. Screening the juices of gooseberry and wild apple for antibacterial and antifungal potentials revealed significant levels of antibacterial action for drug-resistant microbes (methicillin-resistant S. aureus, vancomycinresistant Enterococci, $\beta$-lactamases producing Gram-negative bacteria $)^{76}$. The antimicrobial evaluation of Indian gooseberry and galangal (Alpinia galanga) extracts for $S$. aureus revealed MIC values of 13.97 and $0.78 \mathrm{mg} / \mathrm{ml}$, and minimum biocidal concentration (MBC) of 13.97 and 2.34 $\mathrm{mg} / \mathrm{ml}$, respectively ${ }^{77}$. The antimicrobial activity of the leaves and fruit extracts of $P$. emblica has also been proven for $S$. aureus, $B$. subtilis, $P$. aeruginosa and $E$. coli ${ }^{78}$. Short term use of $P$. emblica fruit gum (sugar free chewing gum prepared by addition of $10 \% P$. emblica fruit extract) was found effective in altering oral microbiome and produced a noteworthy decrease of the total bacterial count and decrease in salivary levels of $S$. mutans and Porphyromonas gingivalis $^{79}$. The inhibition of growth and activity of oral microbes will play a crucial role in prevention of dental caries.

The ethyl acetate EO fruit extract showed powerful inhibitory action for bacterial triggers of autoimmune inflammatory disorder ${ }^{27}$. It acted as an effective inhibitor of $P$. aeruginosa and produced moderate to powerful inhibition of $P$. mirabilis, $K$. pneumoniae and Acinetobacter baylyi. Methanolic and aqueous extracts showed moderate to low inhibition of all tested bacteria. In another study, different Gram negative bacteria ( $P$. aeruginosa, $E$. coli, V. cholera, S. typhi, S. dysenteriae, P. mirabilis, and Providencia alcalifaciens) and Gram positive bacteria ( $S$. aureus, B. subtilis, B. megaterium, B. pumilus, B. cereus, S. pyogenes, B. polymyxa) showed susceptibility to the aqueous and methanolic extracts of EO fruits at 500-1000 $\mathrm{gg} /$ $\mathrm{mL}^{74}$.

Methanolic extract of EO showed good antimicrobial action against E. coli, Salmonella and S. aureus ${ }^{48}$. Owing to potent antibacterial effectiveness of EO essential oil countering $S$. aureus, it can be used for the treatment of diseases involving S. aureus ${ }^{80}$. Antimicrobial assessment of crude powder, aqueous and methanolic extracts of fruit and leaf of EO for S. aureus, K. pneumoniae, and $S$. pyogenes revealed that methanolic extract caused major changes in biochemical features of these pathogens ${ }^{67}$. The antibacterial activity study of amla phenolic extract revealed highest inhibition zone for $S$. aureus followed by Bacillus spp., E. coli and Proteus spp ${ }^{81}$. A comparative study evaluated antimicrobial effectiveness of different agents against the bacteria $E$. faecalis. The zone of microbial growth inhibition of $E$. officinalis was higher than $2.5 \%$ sodium hypochlorite indicating superior antibacterial activity of EO extract ${ }^{72}$. The therapeutic effectiveness of EO fruit extract and procaine penicillin was studied for treating subclinical mastitis in dairy buffaloes ${ }^{73}$. In this 
study, one group received intramammary infusion procaine penicillin at a dose of 2,000,000 I.U and the other group received intramammary infusion of $P$. emblica fruit extract at $1500 \mathrm{mg}(5 \mathrm{ml})$ for 5 days. Both the groups showed slight difference in the cure rate on $7^{\text {th }}$ day, but the percentage of cured animals was moderately higher in the procaine penicillin treated group on day 14 , indicating almost similar efficacy of both treatment protocols in the treatment of subclinical mastitis. Hence intramammary therapy using $P$. emblica fruit extract can be considered as an effective replacement or as an adjunct for antibiotics in buffaloes for management of subclinical mastitis. The organic extracts of EO leaves revealed low to moderate in-vitro antibacterial potential along with bacteriostatic activity countering several antibiotic resistant isolates of the opportunistic fish pathogen E. faecalis. ${ }^{82}$.

\section{Antifungal activity}

The P. emblica extract analyzed for in vitro potential against Fusarium solani, a fungal agent causing dry potato tuber rot revealed inhibition of mycelial growth at a $100 \%$ concentration $^{83}$. The aqueous extract of EO reported significant antifungal activity against eight species of Aspergillus fungi (Aspergillus candidus, A. columnaris, A. flavipes, A. flavus, A. fumigatus, $A$. niger, $A$. ochraceus, and $A$. tamari $)^{84}$. In this study, different solvents employed for the extraction process included Petroleum ether, Chloroform, Methanol, Benzene, and Ethanol. Among different solvents used, methanol extract of EO exhibited superior antifungal activity compared to the other solvents ${ }^{84}$. Ethanol and acetone extracts of fruit had moderate inhibition towards $F$. equiseti and C. albicans, wherein Grisofulvin employed as standard antifungal agent ${ }^{44}$. Plant methanolic extract of EO was not having antifungal activity for phytopathogenic fungus $A$. niger $F 2723^{85}$. The aqueous extracts of EO revealed a diverse degree of antimicrobial action for the pathogenic microbes viz., S. aureus, E. coli and Candida species ${ }^{86}$. The ethanolic extract of EO has been observed to interfere in vitro with adhesion process of $C$. albicans to the human buccal epithelial cells (BECs) and denture acrylic surfaces ${ }^{87}$. E. officinalis extracted using ethanol solvent revealed moderate inhibitory action for S. aureus, S. typhi, B. subtilis, S. dysenteriae and B. megaterium whereas acetone extracts had moderate action for $V$. cholerae, $S$. aureus, B. subtilis and $S$. dysenteriae compared with the standard antibiotic (Amoxicillin) ${ }^{44}$. On antifungal screening, both the extracts possessed moderate activity for $F$. equiseti and $C$. albicans. In this case, griseofulvin was used as the standard antifungal agent ${ }^{44}$. The ethanol, acetone and water (distilled) extracts of EO when assessed for S. mutans, E. faecalis and C. albicans showed minimum inhibitory concentration (MIC) at 0.09\% for ethanolic and acetonic extracts for C. albicans, and at $1.56 \%$ for water extract. MIC of ethanolic extract for E. faecalis was at $3.12 \%$, acetonic extract at $0.39 \%$ and water extract at $12.5 \%{ }^{88}$. Ethyl acetate extract of leaf and bark exhibited maximum potency against Rhizomucor species, whereas methanolic extract showed lowest inhibition against this fungus ${ }^{89}$.

Methanolic extract of amla revealed significant inhibitory action for $S$. aureus, $E$. coli and Candida species as compared with ethyl acetate and aqueous extract ${ }^{86}$. In vitro study with fruit extracts of Sapindus mukorossi and EO against S. mutans, S. aureus, Lactobacillus acidophilus, C. albicans and Saccharomyces cerevisiae depicted fruits of S. mukorossi and EO to have potent antifungal and antibacterial effects, respectively ${ }^{90}$. Triphala inhibited Aspergillus species in vitro by up to $37.96 \%$. Aqueous extracts of fresh fruits have proven potent antimicrobial effects than dry fruits ${ }^{91}$. The antimicrobial potency of the extract from endophytic fungi of EO when tested against E. coli MTCC730, Enteroccocus faecalis MTCC2729, Salmonella enteric ser. Paratyphi MTCC735 and Streptococcus pyogenes MTCC1925, and C. albicans MTCC183 revealed inhibition of the growth of all organisms except $E$. coli $i^{92}$. This might also contribute to the antimicrobial action of different kind of extracts obtained from EO plant. In another study, it was found that seven pathogenic strains of fungi (A. niger, Neurospora crassa, P. chrysogenum, $T$. viride, A. brasiliensis, C. albicans and Cladosporium oxysporum) were found to be susceptible to aqueous extract of EO fruit at a high concentration of $500 \mu \mathrm{g} / \mathrm{mL}^{74}$.

Hexane and methanol extracts of EO when assessed for effectiveness against Fusarium oxysporum and Rhizoctonia solan, revealed that fractions collected from the methanol extract proved more effective against both test 
pathogens ${ }^{93}$. Fraction 112 and 106 possessing 1,2-dihydroxyethyl3,4-dihydroxyfuran-2(5H)-one and 2,3,7,8-tetrahydroxy- chromeno [5,4,3-cde] chromene - 5,10-dione proved most inhibitory to $F$. oxysporum and $R$. solani, respectively. It was also observed that whole fraction exhibited more inhibition than pure constituent(s) isolated from the respective fraction $(s)^{93}$. The antifungal effectiveness of extracts of EO fruits, Aloe vera and Vitex negundo leaves were screened against A. niger, A. flavus, A. oryzae, P. chrysogenum and $T$. viride. All of the plants revealed maximum potential against $T$. viride while $P$. chrysogenum remained as most resistant strain ${ }^{94}$.

\section{Antiviral activity}

$P$. emblica contains different class of secondary metabolites ${ }^{47}$. Phyllaemblicin B extracted from plant roots showed inhibitory potential for Coxsackie virus ${ }^{53,95}$ while phenolic content revealed effectiveness for herpes simplex viruses (HSV) 1 and 296. 1, 2, 4, 6-tetra-O-galloyl-גD-glucose from $P$. emblica showed antiviral activity for HSV in vitro ${ }^{96}$. Pentagalloylglucose inhibits influenza $A$ virus replication by prevention of adsorption of the virus and suppressing release of virus ${ }^{97}$. Several plant extracts possess potential to act against HIV via inhibition of viral enzymes ${ }^{98}$. $P$. emblica plant extracts may have anti-HIV property by inhibiting reverse transcriptase enzyme of the virus ${ }^{99}$. In this study, four solvents were for extraction ( $n$-hexane, carbon tetrachloride, chloroform, aqueous fractions) among which aqueous and $n$-hexane fractions exhibited the highest inhibition of recombinant HIV reverse transcriptase enzyme at $1 \mathrm{mg} / \mathrm{ml}$ concentration ${ }^{99}$. Polyphenolic compound of EO may possess anti-HSV effects via inactivating extracellular viral particles and interfering viral biosynthesis of the host cells, thus might serve as a potential therapeutic candidate against $\mathrm{HSV}^{96}$. Evaluation of the effectiveness of EO extract towards transcriptional activity of human papilloma virus (HPV) revealed inhibition of DNA binding of activator protein-1 (AP-1) in both HPV16- and HPV18- positive cervical cancer cell lines ${ }^{100}$.

An overview on the antimicrobial activities and modes of action of $E$. officinalis is depicted in Fig. 1.

\section{Phytochemicals}

Amla is a precious natural herb that helps maintain and rejuvenate health of humans in various aspects. The health beneficial phytochemicals and antimicrobial potentials of leaf, fruit and bark of amla are now widely proven. The oil extracted from seeds of amla showed antimicrobial activity

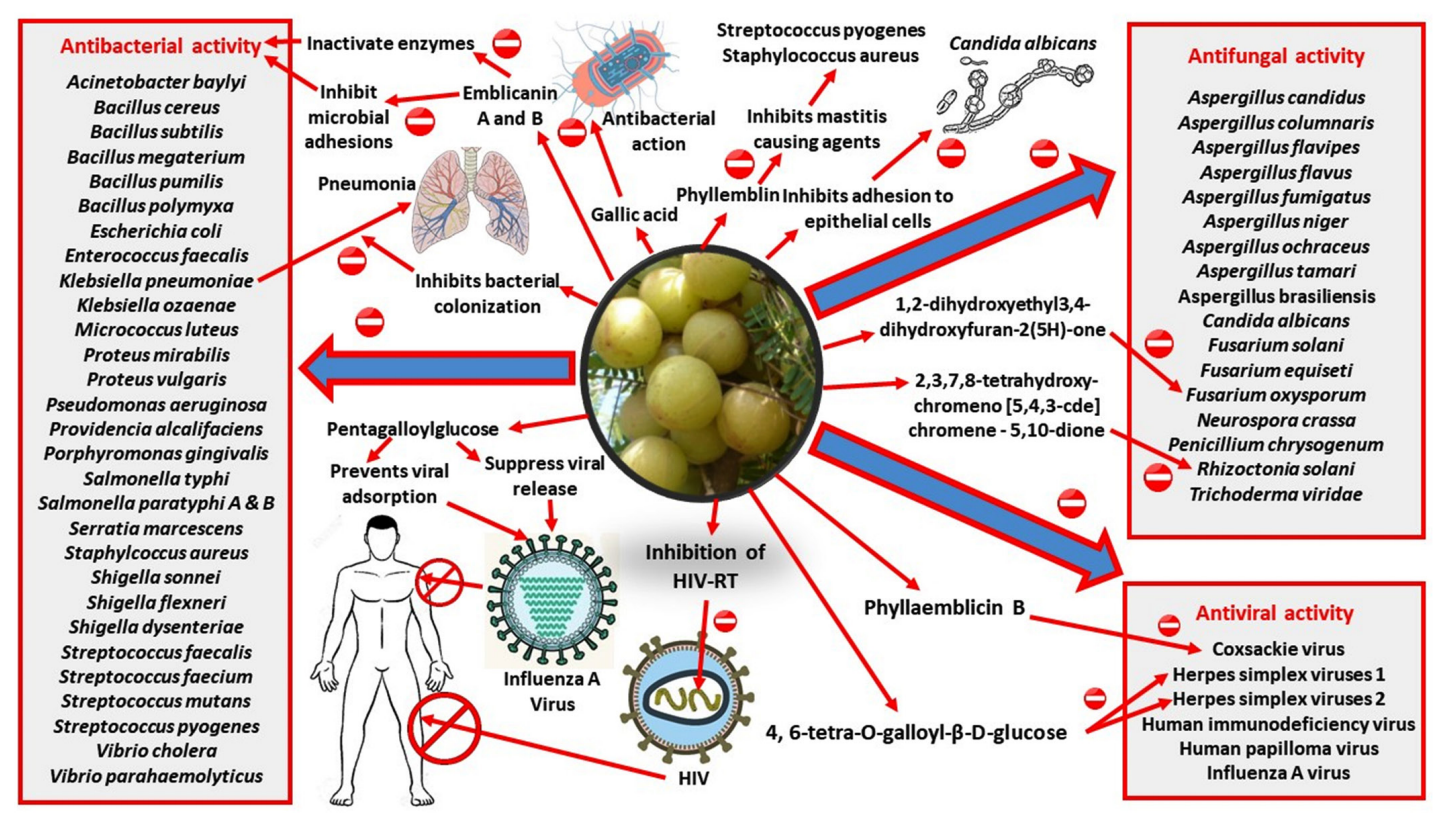

Fig. 1. Antimicrobial activity spectrum of Emblica officinalis and its modes of action 
due to certain biologically active compounds. The crude extract obtained from seeds of amla revealed highest zone of inhibition with regards to antibacterial and antifungal actions as compared to regular drugs ${ }^{45}$. An attempt was made to identify the phytoconstituents in both aqueous and methanolic extracts of EO fruit thereby confirming their antibacterial and antifungal potentials. The aqueous extract contained the compounds 2,4-Ditert-butylphenol $\left(\mathrm{C}_{14} \mathrm{H}_{22} \mathrm{O}\right)$ and Heptasiloxane, 1,1,3,3,5,5,7,7,9,9,11,11,13,13-tetradecamethyl $\left(\mathrm{C}_{14} \mathrm{H}_{44} \mathrm{O}_{6} \mathrm{Si}_{7}\right)$ whereas the compound Phenol, 3,5bis (1,1-dimethylethyl) $\left(\mathrm{C}_{14} \mathrm{H}_{22} \mathrm{O}\right)$ was identified from the methanolic extract ${ }^{74}$. Several important phytoconstituents have been identified in amla like ellagic and gallic acid, emblicanin A and B, quercetin, phyllantine and phyllantidine that possess well established biological actions like antioxidant, anti-inflammatory, antimicrobial, antidiabetic, antitussive, radioprotective, and chemopreventive effects which can be used to manage different diseases ${ }^{37}$. Several types of cultivars are available for $E$. officinalis. An attempt was made recently to assess physical and chemical characteristics of different cultivars (NA-7, NA9, NA-10, Chakaiya, Balwant and Hathijhool) of Indian gooseberry. The study involved comparison of several important parameters like fruit size, volume, moisture content, textural characteristics, and proximate composition. The highest size of fruit was seen in NA-7 cultivar and highest density was seen in Hathijhool cultivar. The levels of ascorbic acid and polyphenol content were also evaluated with level being highest in the Chakaiya cultivar ${ }^{101}$. Hence we have to assume that the phytoconstituents levels may be subjected to change according to the type of cultivars used for the study.

Plant phytochemicals viz., saponins, alkaloids, flavonoids, tannin and other aromatic constituents acting as secondary metabolites provide defenses against several microorganisms ${ }^{17,102}$. Methanol and aqueous extracts of EO fruits revealed existence of alkaloids, tannins, saponins, steroids, phenols, glycosides and flavonoids. Hexane extracts possessed less phytochemicals compared with other extracts that is the cause for its lower antimicrobial actions ${ }^{90,103}$. Seventeen bioactive constituents viz., alcohol, saturated hydrocarbons, unsaturated fatty acid, fatty alcohol, alkane hydrocarbons, vitamin E, ester compounds, plant sterols and triterpenes renders therapeutic potential to EO. Antimicrobial potential of EO may owe to secondary metabolites like 1-hexacosanol, octadecanoic acid, methyl ester, gamma-sitosterol and 12-oleanen-3-yl acetate ${ }^{104}$. Ethyl acetate extract was tested most effective by having higher contents of phytochemicals with significant antibacterial properties. Existence of more bioactive phytochemicals renders higher inhibitory effect to an extract ${ }^{62}$.

The in vitro antimicrobial potential analysis of Emblica essential oils (EOs), obtained by hydrodistillation (HD-EO) and supercritical fluid extraction (SFE-EO), with main components as $\beta$-caryophyllene, $\beta$-bourbonene, 1-octen-3-ol, thymol and methyleugenol, revealed EOs having broad spectrum effects against all bacterial and fungal agents examined. Gram-positive bacteria showed comparatively more sensitivity to EOs than Gram-negative bacteria. SFE-EO showed higher antifungal potential as compared to $\mathrm{HD}-\mathrm{EO}^{105}$. Out of tannins, saponins, flavanoids and phenols present as phytochemicals in EO, the flavonoids and saponins exhibited most inhibitory effects against the pathogens examined ${ }^{67}$.

Phytochemical examination of EO revealed the presence of eblicannin, gallic, ellagic, chebulinic, chebulagic acids, quercetin ${ }^{81}$. The antimicrobial activity of $\mathrm{EO}$ and $M$. arvensis has been recognized because of hydrolysable tannins and menthol, respectively ${ }^{106}$. The fruit protein extracts showed antibacterial action for S. aureus, B. cereus, B. subtilis and E. coli ${ }^{107}$. Methanolic, ethanolic and ethyl acetate extracts of amla fruits and their powders were found to exhibit a powerful antimicrobial action for $E$. coli, Salmonella typhi, S. aureus and C. albicans ${ }^{108}$. Phenolic compounds form complexes with extracellular and soluble proteins or cell walls of bacteria, thus induce disruption in bacterial membrane ${ }^{109}$. The superior antimicrobial potential of EO fruit extract owes to the phenolic compounds others such as phenol, 3,5-bis (1,1-dimethylethyl), 2,4-Di-tert-butylphenol and heptasiloxane, $1,1,3,3,5,5,7,7,9,9,11,11,13,13$-tetradecamethy ${ }^{74}$. Mechanisms of action

Plant extracts possesses potent antimicrobial properties to counter Gram-positive bacteria, owing to differences of bacterial cell 
wall structure (more complex in Gram-negative bacteria) ${ }^{110-112}$. Various modes of antimicrobial actions EO fruits juices are elucidated, although exact targets and mechanisms are not thoroughly understood. Antimicrobial potential is largely ascribed to polyphenols and organic acids ${ }^{113}$. Identifying the specific sites of action may be difficult for natural products owing to several interactive reactions occuring simultaneously ${ }^{114}$. Antibacterial compounds can destroy cell wall and cytoplasmic membrane of the bacteria, resulting in cytoplasm leakage and coagulation, damage proteins, interfere with enzymatic activities, adversely affect DNA and RNA synthesis, lead to disturb electron transport and nutrient uptake, impair energy production and fatty acids and phospholipid constituents are altered inside the cell ${ }^{115,116}$.

Antibacterial properties of EO extracts are mainly attributed to alkaloids, cardiac glucosides, saponins, tannins terepenoids, phenols and flavonoids ${ }^{67}$. Flavonoids inhibit RNA synthesis in microbes owing to their B-ring which participate in intercalation or hydrogen bonding with stacking of nucleic acid bases. Emblicanin A, B and their derivatives also crucially take part in rendering antimicrobial effects ${ }^{117}$. Gooseberry fruits possess high hydrolysable tannins such as emblicanin $A$ and $B$, punigluconin, and pedunculagin ${ }^{118,119}$. Tannins inhibit extracellular microbial enzymes, lead to deprivation of substrate necessary for microbial growth or interferes with metabolism via inhibiting oxidative phosphorylation. Alkaloids such as phyllemblin, flavonoids like kaempferol and phenolic constituents of ellagic and gallic acid have been reported ${ }^{120,121}$. Antimicrobial potential of gooseberry and wild apple owes to phenolic constituents and flavonoids ${ }^{17}$. Phenols control protein to lipid ratio, functioning of membrane and ion channels, while catechins disrupt membrane integrity of lipid bilayers. Kaempferol inhibits protein kinase $\mathrm{C}$ and possess high antibacterial properties for combating multidrug-resistant pathogens (MRSA and VRE) 122,123. Alkaloids may affect genetic materials of the microbes to gain antimicrobial properties ${ }^{113}$.

A broad-spectrum antibacterial pattern in gooseberry and wild apple fruit extracts have been reported ${ }^{124,125}$, the juices and their particles showed superior effects against drug-resistant variants viz., MRSA, VRE and ESBLs. The attainment of drug resistance is not associated with increase innate virulence of microbe ${ }^{126}$. E. officinalis fruit decoction revealed highest antibacterial potential, and then by methanolic extract of its leaves. S. aureus was observed to be most sensitive followed by S. pyogenes, while K. pneumoniae got moderately inhibited due capsular polysaccharide surrounding interfering with antimicrobial effects of EO leaf and fruit extracts ${ }^{110}$.

\section{Amla: Antimicrobial nanoparticles}

The rising concerns of emerging microbial resistance for antibiotics has paved way for designing of antimicrobial nanoparticles (NPs) such as silver NPs (AgNPs) and selenium NPs (SeNPs) ${ }^{75,127}$. Biogenic production of AgNPs from the plant sources is getting popularity in the present scenario, this is mainly because of the low cost factor when compared to the conventional chemical synthesis method ${ }^{127}$. AgNPs are ever more being utilized in therapeutics and diagnosis owing to their typical physical, chemical and antibacterial properties. Many theories of antibacterial activity of colloidal silver solution are proposed, it can change permeability of cell membrane, affects release of lipopolysaccharides and membrane proteins, free radical accountable for membrane damage, and dissipation of proton motive force leading to collapse of membrane potential; but exact modes need to be yet fully elucidated $^{128}$. The size of AgNPs formed also affects the antibacterial activity, smaller AgNPs with large surface area for communication show stronger antibacterial actions. Using plant sources for synthesis of AgNPs will be economic, less toxic, more effective, and also an environment friendly approach $^{127,129}$. We can use fresh fruit extract of EO as a stabilizing, reducing, and capping agent in process of silver nanoparticle preparation ${ }^{127}$.

AgNPs have shown potent antimicrobial effects in countering $E$. coli, S. aureus and $S$. marcescens ${ }^{130-132}$. It also showed antinematode ${ }^{133}$, antiviral $^{134}$, anticancer ${ }^{135,136}$ and anti-inflammatory effects $^{137}$. Aqueous $P$. emblica fruit extract when evaluated against eight pathogenic cultures and its applicability in green synthesis of AgNPs showed that all the test cultures were inhibited by the AgNPs and the average ZOI measured $19.25 \pm 2.7 \mathrm{~mm}^{129}$. The AgNPs produced from fresh aqueous EO fruit extract possessed antibacterial 
effects for gram negative and positive bacteria. Evaluation of $P$. emblica methanolic seed extract and palladium nanoparticles (PdNPs) against four different pathogens revealed that seed extract had maximum $\mathrm{ZOI}$ against $B$. subtilis followed by $S$. aureus, while PdNPs had maximum ZOI against $S$. aureus followed by $P$. aeruginos ${ }^{138}$. MIC results reflected $B$. subtilis to be inhibited at lower concentration for extract and PdNPs. The most resistant pathogen was found to be $P$. mirabilis as compared to other microbes ${ }^{138}$. Comparative studies of methanol extract and zinc oxide NPs revealed green synthesized zinc oxide NPs from EO to be effective antibacterial in traditional system of medicine ${ }^{139}$. The EO aqueous fruit extract has been used to produce phytofabricated selenium NPs (PF-SeNPs) by reducing it with sodium selenite $^{75}$. The PF-SeNPs had antimicrobial activity against several food-borne pathogens. Due to this peculiarity it is having wide application in food and pharmaceutical industry. These PF-SeNPs have superior activity against fungi, and then for Gram positive and negative bacteria. Cytotoxicity study suggested PF-SeNPs to be safer and less toxic when compared to the sodium selenite ${ }^{75}$. In this study, PF-SeNPs exhibited concentration dependent antioxidant effect (directly proportional relationship between concentration of PF-SeNPs and its corresponding antioxidant effect) along with effective antimicrobial properties for both bacterial and fungal pathogens.

Fresh fruit extract of EO has been utilized for synthesizing AgNPs. Based on in vitro antibacterial sensitivity test, it was found that the synthesized nanoparticle showed significant level of activity for bacteria Acidovorax oryzae strain RS-2, a pathological agent causing bacterial brown stripe in rice plant ${ }^{127}$. An attempt was made to incorporate plant extracts into nanofiber scaffold so that its biological functions can be modified. E. officinalis loaded poly(I-caprolactone) (PCL) nanofibers have been produced to incorporate antibacterial and anti-cancerous activity into the scaffold ${ }^{140}$. The nanofiber scaffold loaded with EO possessed remarkable antibacterial action for Gram positive and negative bacteria with greater antibacterial effect for Gram positive bacteria ${ }^{140}$. Such nanofiber scaffolds containing EO extracts can be considered as the suitable candidates for wound management in infected wounds and cancer patients.

\section{Other potential health applications of Amla}

The other beneficial health effects of E. officinalis comprise of anti-oxidative, antiinflammatory, anti-diabetic, anti-hyperlipidemic, anti-cancer, anti-mutagenic, cardioprotective, and

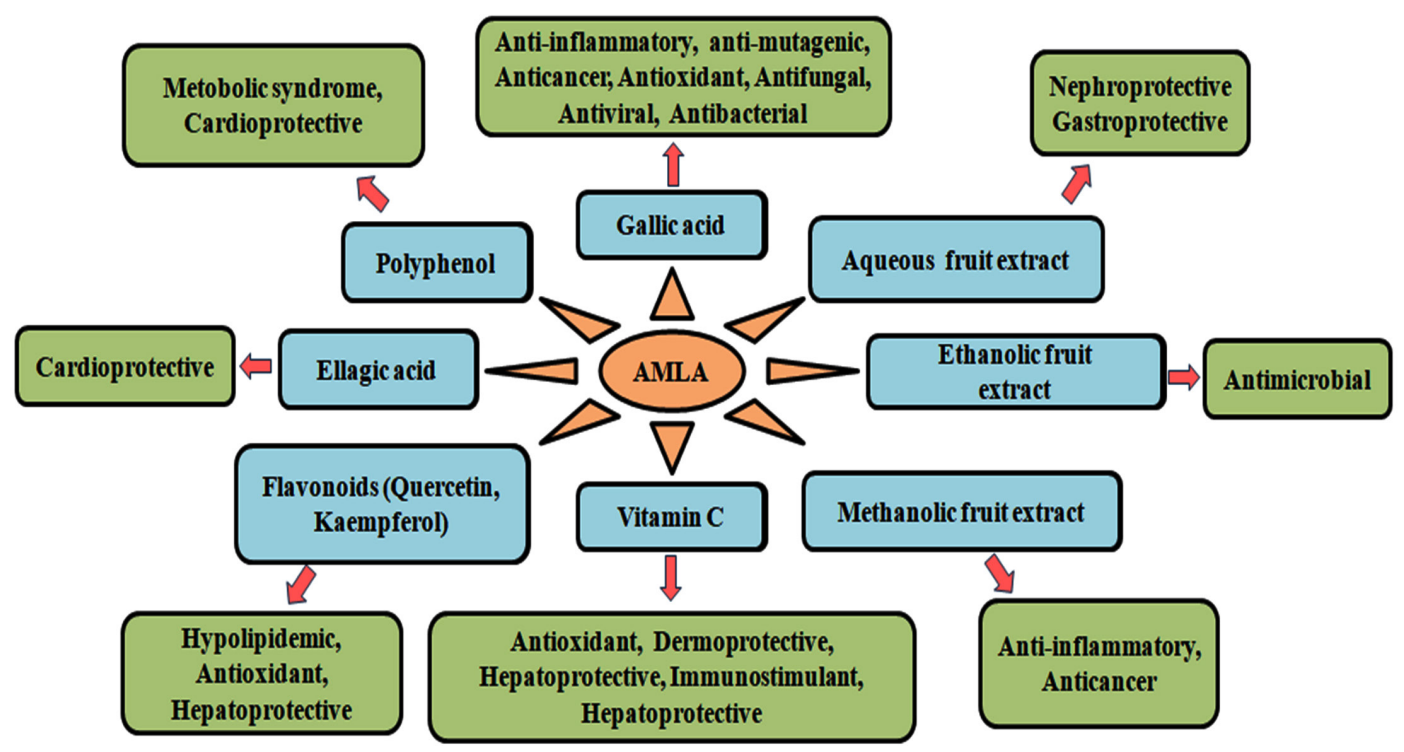

Fig. 2. Therapeutic activities of solvent extract and compounds of Emblica officinalis 
hepatoprotective modes of action ${ }^{68,141-143}$ (Fig. 2). Gallic acid equivalent as total phenolic substance of EO fruit and seed possesses remarkable antioxidant actions and as free radical scavengers necessary in maintaining redox homeostasis ${ }^{144}$. Methanolic seed extract of EO showed potent free radical scavenging property of 1, 1, Diphenyl-2-picrylhydrazil (DPPH) in a concentration dependant mode $^{145}$. Saponins present in EO show insecticidal or cytotoxic activity against some of the insects ${ }^{146}$. The methanol extract of EO produced larvicidal and pupicidal activities combating malarial vector (Anopheles stephensi), presenting 98\% mortality at 100 ppm $^{147}$. Antidepressant potential of aqueous extract of EO fruits as assessed in inbred male Swiss albino mice (25-30g) revealed comparable effects with the drug imipramine, which suggest it to be a suitable candidate as an adjuvant in the treating several nervous disorders ${ }^{148}$. Water extract of EO showed inhibitory consequence on production and release of inflammatory mediators in rats ${ }^{149}$. EO extract treatment of mice previous to exposure of different doses of gamma radiation has been found to decrease magnitude of symptoms of radiation sickness and mortality ${ }^{150}$. Amla fruit also possesses remarkable antihyperlipidemic, hypolipidemic, and antiatherogenic effect ${ }^{151}$. Efficacy trial of $P$. emblica aqueous fruit extract on triglycerides (TG) and liver-specific enzyme, alanine transaminase (ALT) levels, revealed that at a dose of $200 \mathrm{mg} / \mathrm{kg}$ body weight it significantly trim down blood glucose in alloxan induced diabetic rats ${ }^{152}$. The oral feeding of low dose EO extract in mice for two weeks resulted in significant increase in plasma free fatty acids which could be due to increased lipolysis or decreased adipose tissue lipid storage ${ }^{153}$. In a study conducted with chewing gum containing $P$. emblica fruit extract it was found that a short term use of the gum stimulates the salivary flow which altered the $\mathrm{pH}$ levels ${ }^{79}$. It also reduced the volatile sulfur compound concentrations which was critical in reducing the oral malodor.

E. officinalis has also been evaluated for its curative application against various neurodegenerative disorders like dementia, Alzheimer's disease and Parkinson's disease ${ }^{154}$. Phytochemicals such as quercetin, gallic acid, corilagin and ellagic acid in amla put forth hepatoprotective effects to alleviate toxicity of paracetamol, microcystins, galactosamine and lipopolysaccharide. Such health protective actions owe to antioxidant, anti-inflammatory and hypolipidemic properties and modulating detoxifying enzymes ${ }^{155}$. EO also possesses powerful memory enhancing actions, reducing cholesterol levels and ameliorating ophthalmic disorder ${ }^{24}$. Prebiotics have been found effective in management of gut microbiota dysbiosis, however produce side effects during long period usage such as abdominal bloating and flatulence. As an option to prebiotics, EO extracts have been assessed for their potency in modulating gut microflora, high dose of oral supplementation caused increased microbial quantity of Eubacterium genus of Eubacteriaceae family, however overall microbial diversity was not affected ${ }^{153}$.

In Ayurvedic medicine, Amla oil has been used for its beneficial roles in hair nourishment and as scalp tonic ${ }^{10,156,157}$. It has also been investigated for its antimicrobial and therapeutic purposes to combat several diseases and disorders including the deadly malady of cancers ${ }^{15,18,23,157}$. Anticancer modes of actions of Amla comprise of free radical and antioxidant properties, modulation of inflammatory enzymes, carcinogenesis, and cell cycle proteins, induction of apoptosis in neoplastic cells, and preventing the process of metastasis ${ }^{158}$. E. officinalis seed extract has been found to induce cell death in human cervical cancer cells, thus making it a suitable candidate for its treatment ${ }^{138}$. Antiproliferative activity of extracts of Indian gooseberry was also observed ${ }^{159}$. Promising anti-plasmodial effectiveness observed in the EO leaf extracts may serve for their utility as antimalarial agents even in crude form, and also to be even effective against Chloroquineresistant strains ${ }^{160}$. The extracts of EO expressed in vivo anti-plasmodial effects with appropriate suppression ranging from 53.40 to $69.46 \%^{161}$. Chyawanprash is a commercially available brand of Ayurvedic health supplement that is available throughout the India. It is concentrate made up of several herbs and minerals. $E$. officinalis is an important herbal component of chyawanprash due to its immunomodulatory, rejuvenative, neuroprotective, hepatoprotective, antioxidant, and cardiotonic activity. It also 
enhances the general vitality and cognitive function in the consumers ${ }^{162}$. The constituents that are responsible for these activities are 6-ethenyl-4,5,6,7-tetrahydro-3,6-dimethyl-5isopropenyl-trans-benzofuran, 8,9-dehydro9formyl-cycloisolongifolene, $\gamma$-elemene and eucalyptol ${ }^{162}$.

Multiple beneficial health applications including the potent antimicrobial properties, medicinal and therapeutic values of Emblica officinalis need to be promoted and propagated with more researches and clinical trials, validation studies, promotional activities along with exploration of advances in biotechnology, pharmacology, pharmaceuticals, nanotechnology based approaches for developing effective drugs and medicines utilizing Amla ${ }^{6,15-17,24,75,139,163-}$ 165. Particularly, in the scenario of rising drug resistance, higher incidences of emerging and reemerging pathogenic microbes, the antimicrobial efficacy of Emblica officinalis can be exploited for important microbial pathogens including food-borne zoonotic bacteria such as Salmonella, Arcobacters, Camyplobacters, and emerging viral pathogens like Zika, Ebola, Nipah virus and others, so as to lessen their high incidences, devastating effects and public health effects; since various other herbs and plant metabolites / extracts have shown promising results against such pathogens $s^{5,6,166-169}$.

\section{CONCLUSION}

Researchers are now trying to fill the lacunae of conventional drugs by exploring the traditional medicinal herbs. Emblica officinalis is a well recognized herb in Indian indigenous system of medicine. Different types of extracts and herbal formulations derived from Amla have shown tremendous therapeutic and beneficial health effects in countering several diseases and disorders. Several well established activities have been credited to the EO extracts which include antibacterial, antifungal, antiviral, antiinflammatory, antioxidant, cryoprotective, antiaging, nephrotoxicity modulation, antidiabetic, hepatoprotective, anti-hyperlipidemic, insecticidal, anti-cancer, anti-atherogenic, antiproliferative, anti-diarrheal, immunomodulator, gastroprotective, cardioprotective, neuroprotective, and radio-protective activity.
Even though several researches for qualitative analysis of phytochemicals has been done, further quantitative analysis of EO extracts for potent phytochemicals is necessary especially for assessment of their antimicrobial potential. Exploring the various mechanisms of action owing to antibacterial potential of specific compounds / constituents present in the plant extracts, would pave way forward for more usages of such natural herbs for countering microbial pathogens in an effective way by developing potent antimicrobial drugs and medicines as well as to alleviate the problem of emerging antimicrobial resistance. Appropriate actions must be taken to continue studies for designing and development of natural products from Amla for safeguarding various health issues. Another paramount research importance should aim to identify the phytochemical constituents of EO extract rendering specific activities. This will enable us to synthetically produce the identified active ingredient at a large scale so that further studies can be conducted to develop new commercial drugs that are basically originated from the natural sources.

\section{ACKNOWLEDGEMENTS}

All authors acknowledge their Institutes and Universities.

\section{CONFLICTS OF INTEREST}

The authors declare that there is no conflict of interest.

\section{AUTHOR CONTRIBUTIONS}

All authors contributed significantly and equally.

\section{FUNDING}

None.

\section{DATA AVAILABILITY}

This review manuscript has been compiled with information available in PubMed, PubMed Central, Science Direct and other scientific databases.

\section{ETHICS STATEMENT}

The manuscript has been drafted with full responsibility, following due ethical 
procedure, and there is no duplicate publication, fraud, plagiarism, or concerns about animal or human experimentation while maintain research compilation integrity.

\section{REFERENCES}

1. Mahima, Rahal, A, Deb, R, Latheef, SK, Samad, HA, Tiwari, R, Verma, AK, Kumar, A, Dhama, K. Immunomodulatory and therapeutic potentials of herbal, traditional / indigenous and ethnoveterinary medicines. Pak. J. Biol. Sci., 2012; 15(16): 754-774. https://doi.org/10.3923/pjbs.2012.754.774

2. Edwards, S, Lawrence, MJ, Cable, C, Heinrich, M. Where do herbal medicines belong? Part 1-An overview of CAM. Pharm. J., 2012; 288(7704): 565.

3. Dhama, K, Tiwari, R, Chakraborty, S, Saminathan, $M$, Kumar, A, Karthik, K, Wani, MY, Amarpal, SS, and Rahal, A. Evidence based antibacterial potentials of medicinal plants and herbs countering bacterial pathogens especially in the era of emerging drug resistance: An integrated update. Int. J. Pharmacology, 2014; 10(1): 1-43. https://doi.org/10.3923/ijp.2014.1.43

4. Dhama, K, Latheef SK Saminathan Mani, Samad, HA, Karthik K, Tiwári, R, Khan, RU, Alagawany, M, Farag, MR, Alam, GM, Laudadio, V and Tufarelli, V. Multiple beneficial applications and modes of action of herbs in poultry health and production - A review. Int. J. Pharmacol., 2015; 11(3): 152-176. https://doi. org/10.3923/ijp.2015.152.176

5. Dhama, K, Karthik, K, Khandia, R, Munjal, A, Tiwari, R, Rana, R, Khurana, SK, Ullah, S, Khan, RU, Alagawany, M, Farag, MR, Dadar, M, Joshi, SK. Medicinal and therapeutic potential of herbs and plant metabolites/ extracts countering viral pathogens-current knowledge and future prospects. Curr. Drug Metab., 2018; 19(3): 236-263. https://doi.org/10.2174/138920021966618 0129145252

6. Tiwari, R, Latheef, SK, Ahmed, I, Iqbal, H, Bule, MH, Dhama, K, Samad, HA, Karthik, K, Alagawany, M, El-Hack, ME. Yatoo, MI, Farag, MR. Herbal Immunomodulators - A Remedial Panacea for Designing and Developing Effective Drugs and Medicines: Current Scenario and Future Prospects. Curr. Drug Metab., 2018; 19(3): 264-301. https://doi. org/10.2174/1389200219666180129125436

7. Vashist, $\mathrm{H}$, Jindal, A. Antimicrobial activities of medicinal plants-Review. Int. J. Res. Pharm. Biomed. Sci., 2012; 3(1): 222-230.

8. Patel, S, Goyal A. Recent developments in mushrooms as anti-cancer therapeutics: A review. 3 Biotech., 2012; 2(1): 1-15. https://doi.org/10.1007/s13205-011-00362

9. Zameer, S, Najmi, AK, Vohora D, Akhtar M. A review on therapeutic potentials of Trigonellafoenum graecum (fenugreek) and its chemical constituents in neurological disorders: complementary roles to its hypolipidemic, hypoglycemic and antioxidant potential. Nutr. Neurosci., 2018; 21(8): 539-545. https://doi.org/10.1080/1028415X.2017.1327200

10. Mirunalini, S, Krishnaveni, M. Therapeutic potential of Phyllanthus emblica (amla): The ayurvedic wonder. J.
Basic Clin. Physiol. Pharmacol., 2010; 21(1): 93-105.

11. Patel, JR, Tripathi, P, Sharma V, Chauhan, NS, Dixit, VK. Phyllanthus amarus: Ethnomedicinal uses, phytochemistry and pharmacology: A review. J. Ethnopharmacol., 2011; 138(2): 286-313. https://doi. org/10.1016/j.jep.2011.09.040

12. Thilakchand, KR, Mathai, RT, Simon, P, Ravi, RT, BaligaRao, MP, Baliga, MS. Hepatoprotective properties of the Indian gooseberry (Emblica officinalis.Gaertn): a review. Food Funct., 2013; 4(10): 1431-1441. https:// doi.org/10.1039/c3fo60237k

13. Vasant, BS, Bhaskarrao, DA, Bhanudas, SR. Emblica officinalis-The wonder of Ayurvedic medicine. W. J. Pharm. Pharm. Sci., 2013; 3(1): 285-306.

14. D'souza, JJ, D'souza, PP, Fazal, F, Kumar, A, Bhat, HP, Baliga, MS. Anti-diabetic effects of the Indian indigenous fruit Emblica officinalis Gaertn: active constituents and modes of action. Food Funct., 2014; 5(4): 635-644. https://doi.org/10.1039/c3fo60366k

15. Variya, BC, Bakrania, AK, Patel, SS. Emblica officinalis (Amla): A review for its phytochemistry, ethnomedicinal uses and medicinal potentials with respect to molecular mechanisms. Pharmacol. Res., 2016; 111: 180-200. https://doi.org/10.1016/j.phrs.2016.06.013

16. Yadav, SS, Singh, MK, Singh, PK, Kumar, V. Traditional knowledge to clinical trials: A review on therapeutic actions of Emblica officinalis. Biomed. Pharmacother., 2017; 93: 1292-1302. https://doi.org/10.1016/j. biopha.2017.07.065

17. Lanka, DS. A review on pharmacological, medicinal and ethnobotanical important plant: Phyllanthus emblica linn. (syn. Emblica officinalis). W. J. Pharm. Res., 2018; 7(4): 380-396.

18. Baliga, MS, Dsouza, JJ. Amla (Emblica officinalis Gaertn), a wonder berry in the treatment and prevention of cancer. Eur. J. Cancer Prev., 2011; 20(3): 225-239. https://doi.org/10.1097/CEJ.0b013e32834473f4

19. Patil, SG, Deshmukh, AA, Padol, AR, Kale, DB. In vitro antibacterial activity of Emblica officinalis fruit extract by tube dilution method. Int. J. Toxicol. Appl. Pharmacol., 2012; 2(4): 49-51.

20. Facts, O. Health benefits of Indian gooseberry or amla; 2016. https://www.organicfacts.net/ health-benefits/ fruit/indian-gooseberry-amla.html.

21. Kulkarni, K.V., Ghurghure, S.M. Indian gooseberry (Emblica officinalis): Complete pharmacognosy review. Int. J. Chem. Stud., 2018; 2(2): 5-11.

22. Kumar, KS, Bhowmik, D, Dutta, A, Yadav, AP, Paswan, S, Srivastava, S, Deb, L. Recent trends in potential traditional Indian herbs Emblica officinalis and its medicinal importance. J. Pharmacogn. Phytochem., 2012; 1(1): 18-28.

23. Baby, B, Antony, P, Vijayan, R. Antioxidant and anticancer properties of berries. Crit. Rev. Food Sci. Nutr., 2018; 58(15): 2491-2507. https://doi.org/10.1 080/10408398.2017.1329198

24. Jain, R, Pandey, R, Mahant, RN, Rathore, DS. A review on medicinal importance of Emblica officinalis. Int. J. Pharm. Sci. Res., 2015; 6(1): 72-84.

25. Upadhyay, RK. Plant natural products: Their pharmaceutical potential against disease and drug resistant microbial pathogens. J. Pharm. Res., 2011; 
4(4): 1179-1185.

26. Jamali, MC. antimicrobial activity of Phyllanthus emblica. J. Bio Innov., 2016; 5(6): 979-984.

27. Hutchings, A, Cock IE. An interactive antimicrobial activity of Embelica officinalis Gaertn. fruit extracts and conventional antibiotics against some bacterial triggers of autoimmune inflammatory diseases. Pharmacogn. J., 2018; 10(4): 654-662. https://doi.org/10.5530/ pj.2018.4.108

28. Singh, SN, Moses, A, David, A. Antimicrobial activity of Emblica officinalis extracts against selected bacterial pathogens. Int. J. Basic Appl. Res., 2019; 9(1): 325-330.

29. Golechha, M, Sarangal, V, Ojha, S, Bhatia, J, Arya, DS. Anti-inflammatory effect of Emblica officinalis in rodent models of acute and chronic inflammation: Involvement of possible mechanisms. Int. J. Inflam., 2014; 178408. https://doi.org/10.1155/2014/178408

30. Yamamoto, H, Morino, K, Mengistu, L, Ishibashi, T, Kiriyama, K, Ikami, T, Maegawa, H. Amla enhances mitochondrial spare respiratory capacity by increasing mitochondrial biogenesis and antioxidant systems in a murine skeletal muscle cell line. Oxid Med. Cell Longevity, 2016; 1735841. https://doi. org/10.1155/2016/1735841

31. Packirisamy, RM, Bobby, Z, Panneerselvam, S, Koshy, $\mathrm{SM}$, Jacob, SE. Metabolomic analysis and antioxidant effect of amla (Emblica officinalis) extract in preventing oxidative stress induced red cell damage and plasma protein alterations: an in vitro study. J. Med. Food, 2017; 21(1): 81-89. https://doi.org/10.1089/ jmf.2017.3942

32. Zhang, Y, Zhao, L, Guo, X, Li, C, Li, H, Lou, H, Ren, D. Chemical constituents from Phyllanthus emblica and the cytoprotective effects on $\mathrm{H}_{2} \mathrm{O}_{2}$-induced $\mathrm{PC}_{2}$ cell injuries. Arch. Pharmacol. Res., 2016; 39(9): 12021211. https://doi.org/10.1007/s12272-014-0433-2

33. Pientaweeratch, S, Panapisal, V, Tansirikongkol, A. Antioxidant, anti-collagenase and anti-elastase activities of Phyllanthus emblica, Manilkarazapota and silymarin: An in vitro comparative study for anti-aging applications. Pharm. Biol., 2016; 54(9): 1865-1872. https://doi.org/10.3109/13880209.2015.1133658

34. Malik, S, Suchal, K, Bhatia, J, Khan, SI, Vasisth, S, Tomar, A, Goyal, S, Kumar, R, Arya, DS, Ojha, SK. Therapeutic potential and molecular mechanisms of Emblica officinalis Gaertn in countering Nephrotoxicity in rats induced by the chemotherapeutic agent Cisplatin. Front. Pharmacol., 2016; 7:350. https://doi. org/10.3389/fphar.2016.00350

35. Fatima, N, Hafizur, RM, Hameed, A, Ahmed, S, Nisar, $\mathrm{M}, \mathrm{Kabir}, \mathrm{N}$. Ellagic acid in Emblica officinalis exerts anti-diabetic activity through the action on $\beta$-cells of pancreas. Eur. J. Nutr., 2017; 56(2), 591-601. https:// doi.org/10.1007/s00394-015-1103-y

36. Huang, $\mathrm{CZ}$, Tung, YT, Hsia, SM, Wu, CH, Yen, GC. The hepatoprotective effect of Phyllanthus emblica L. fruit on high fat diet-induced non-alcoholic fatty liver disease (NAFLD) in SD rats. Food Funct., 2017; 8(2), 842-850. https://doi.org/10.1039/C6FO01585A

37. Hasan, MR, Islam, MN, Islam, MR. Phytochemistry, pharmacological activities and traditional uses of Emblica officinalis: A review. Int. Curr. Pharm. J.,
2016; 5(2): 14-21. https://doi.org/10.3329/icpj. v5i2.26441

38. Tiwari, R, Chakraborty, S, Dhama, K, Rajagunalan, S, Singh, SV. Antibiotic resistance - an emerging health problem: causes, worries, challenges and solutions - a review. Int. J. Curr. Res., 2013; 5(07): 1880-1892.

39. Bag, A, Bhattacharyya, SK, Pal, NK., Chattopadhyay RR. In vitro antimicrobial potential of Terminalia chebula fruit extracts against multidrug-resistant uropathogens. Asian Pac. J. Trop. Biomed., 2012; 2(3): 1883-1887. https://doi.org/10.1016/S22211691(12)60514-0

40. Yadav, AS, Kolluri, G, Gopi, M, Karthik K, Malik YS, Dhama K. Exploring alternatives to antibiotics as health promoting agents in poultry- a review. J. Exp. Biol. Agri. Sci., 2016; 4(3s): 368-383. https://doi. org/10.18006/2016.4(3S).368.383

41. Kumar, A, Tantry, BA, Rahiman, S, Gupta, U. Comparative study of antimicrobial activity and phytochemical analysis of methanolic and aqueous extracts of the fruit of Emblica officinalis against pathogenic bacteria. J. Tradit. Chin. Med., 2011; 31: 246250.

42. Gupta, P, Nain, P, Sidana, J. Antimicrobial and antioxidant activity on Emblica officinalis seed extract. Int. J. Res. Ayurv. Pharm., 2012; 3(4): 591-596.

43. Khopde, SM, Priyadarsini, KI, Guha, SN, Satav, JG, Venkatesan, P, Rao, MN. Inhibition of radiationinduced lipid peroxidation by tetrahydrocurcumin: possible mechanisms by pulse radiolysis. Biosci. Biotechnol. Biochem., 2000; 64(3): 503-509. https:// doi.org/10.1271/bbb.64.503

44. Hossain, MM, Mazumder, K, Hossen, SM, Tanmy, $\mathrm{TT}$, Rashid, MJ. In vitro antibacterial and antifungal activities of Emblica officinalis. Int. J. Pharm. Sci. Res., 2012; 3(4): 1124-1127.

45. Anbuselvi, $\mathrm{S}, \mathrm{Jha}, \mathrm{M}$. Phytochemical and antimicrobial activity of Emblica officinals seed extract. W. J. Pharm. Res., 2015; 4(8): 1336-1341.

46. Gautam, A., Shukla, S. Emblica officinalis (Amla) leaf extract potentiates antibacterial activity of some antibiotics. J. Pharmacogn. Phytochem., 2017; 6(2): 233-236.

47. Calixto JB, Santos AR, Filho VC, Yunes RA. A review of the plants of the genus Phyllanthus: Their chemistry, pharmacology and therapeutic potential. Med. Res. Rev., 1998; 18(4): 225-258. https://doi.org/10.1002/ (SICI)1098-1128(199807)18:4\%3C225::AIDMED2\%3E3.0.CO;2-X

48. Gurav NI, Solanki BH, Pandya KR, Patel PR. Physicochemical and antimicrobial activity of single herbal formulation-capsule, containing Emblica officinalis Gaertn. Int. J. Pharm. Pharm. Sci., 2011; 3: 383-386.

49. Nandagopal B., Sankar S., Ramamurthy M., Sathish S., Sridharan G. Could the products of Indian medicinal plants be the next alternative for the treatment of infections? Indian J. Med. Microbiol., 2011; 29(2): 93 101. https://doi.org/10.4103/0255-0857.81775

50. Hossen SM, Sarkar R, Mahmud S, Aziz NA. Medicinal potential of Phyllanthus emblica (Linn.) fruits extracts: Biological and pharmacological activities. British J. Pharm. Res., 2014; 4(12): 1486-1499. https://doi. 
org/10.9734/BJPR/2014/10307

51. Rani P, Khullar N. Antimicrobial evaluation of some medicinal plants for their antienteric potential against multi-drug resistant Salmonella typhi. Phytother. Res., 2004; 18(8): 670-673. https://doi.org/10.1002/ ptr.1522

52. Rahman S, Akbor MM., Howlader A, Jabbar A. Antimicrobial and cytotoxic activity of the alkaloids of Amlaki (Emblica officinalis). Pak J. Biolsci., 2009; 12(16): 1152-1155. https://doi.org/10.3923/ pjbs.2009.1152.1155

53. Liu Q, Wang YF, Chen RJ, Zhang MY, Wang YF, Yang CR, Zhang YJ. Anti-coxsackie virus B3 norsesquiterpenoids from the roots of Phyllanthus emblica. J. Nat. Prod., 2009; 72(5): 969-972.

54. Maji, S, Dandapat, P, Ojha, D, Maity, C, Halder, SK, Mohapatra, PKD, Pathak, TK, Pati, BR, Samanta, A and Mondal, KC. In vitro antimicrobial potentialities of different solvent extracts of ethnomedicinal plants against clinically isolated human pathogens. J. Phytol.. 2010; 2(4): 57-64.

55. Srikumar R, Parthasarathy NJ, Manikaordan S, Narayanan GS, Sheeladevi R. Effect of Triphala on oxidative stress and on cell-mediated immune response against noise stress in rats. Mol. Cell Biochem., 2006; 283(1-2): 67-74. https://doi.org/10.1007/s11010-0062271-0

56. Saeed S., Tariq P. Antibacterial activities of Emblica officinalis and Coriandrum sativum against Gram negative urinary pathogens. Pak. J. Pharm. Sci., 2007; 20(1): 32-35.

57. Saini A, Sharma S, Chhibber S. Protective efficacy of Emblica officinalis against Klebsiella pneumoniae induced pneumonia in mice. Indian J. Med. Res., 2008; 128(2): 188-193.

58. Mehrotra S, Srivastava AK, Nandi SP. Comparative antimicrobial activities of Neem, Amla, Aloe, Assam Tea and Clove extracts against Vibrio cholerae, Staphylococcus aureus and Pseudomonas aeruginosa. J. Med. Plants Res., 2010; 4(23): 2473-2478.

59. Jadon R, Dixit S. Phytochemical extraction and antimicrobial activity of some medicinal plants on different microbial strains. J. Med. Plants Studies, 2014; 2(3): 58-63.

60. Bole SB, Manju R, Nagaraj M, Sandhya $V$, Supriya G, Kumari P, Kiran B, Lalitha V. Comparative study of antibacterial and antioxidant activity of plant extract-Amla [Phyllanthus emblica L.] Tulsi [Ocimum tenuiflorum L.] Neem [Azadirachta indica A. Juss]. Pharmacophore, 2010; 1(3): 178-183.

61. Kanthimathi M, Soranam R. Antibacterial effects of Emblica officinalis and Phyllanthus niruri crude extracts against bacterial pathogens. Int. J. Pharm. Clin. Sci., 2013; 3(3): 20-23.

62. Dharajiya D, Patel P, Moitra N. Antibacterial activity of Emblica officinalis (Gaertn.) fruits and Vitex negundo (L.) leaves. Curr. Trends Biotechnol. Pharm., 2015a; 9: 357-368.

63. Rawat S. Antimicrobial activity of medicinal plants against urinary tract infection pathogens. IJAPRR Int. Peer Rev. Ref. J., 2015; 2(2): 69-74.

64. Saradha Jyothi, K., \& Subba Rao, B. Screening of antibacterial activity of Emblica officinalis fruits. Pharmacology Online, 2011; 3: 848-852.

65. Raghu HS, Ravindra P. Antimicrobial activity and phytochemical study of Phyllanthus emblica Linn. Int. J. Pharm. Studies Res., 2010; 1(1): 30-33.

66. Ghosal S, Tripathi VK, Chauhan S. Active constituents of Emblica officinalis : Part 1. The chemistry and antioxidative effects of two new hydrolysable tannins, emblicanin A and B. Indian J. Chem., 1996; 35(9): 941948.

67. Javale $\mathrm{P}$, Sabnis $\mathrm{S}$. Antimicrobial properties and phytochemical analysis of Emblica officinalis. Asian J. Exp. Biol. Sci. Spec., 2010; 1: 91-95.

68. Nain P, Saini V, Sharma S. In-vitro antibacterial and antioxidant activity of Emblica officinalis leaves extract. Int. J. Pharm. Pharm. Sci., 2012; 4(1): 385-389.

69. Varghese LS, Ninan MA, Alex N, Soman S, Jacob SI. Comparative antibacterial activity of fruit extracts of Emblica officinalis Gaertn. against Gram positive versus Gram negative bacteria. Biomed. Pharmacol. J., 2013; 6(2): 447-452. https://doi.org/10.13005/bpj/441

70. Elangovan NM, Dhanarajan MS, Elangovan I. Evaluation of antibacterial and antifungal activity of Phyllanthus emblica leaf extract. Int. Res. J. Pharm. Biosci., 2015; 2(2): 59-66.

71. Jahan N, Akter S. Assessment of the antimicrobial activity of the ethanolic extract of Phyllanthus emblica in combination with different classes of antibiotics against single and multi-drug resistant strains. $J$. Pharmacogn. Phytochem., 2015; 4(4): 142-155.

72. Dubey, S. Comparative antimicrobial efficacy of herbal alternatives (Emblica officinalis, Psidium guajava), MTAD, and $2.5 \%$ sodium hypochlorite against Enterococcus faecalis: An In vitro study. J. Oral Biol. Craniofac. Res., 2016; 6(1), 46-49. https://doi. org/10.1016/j.jobcr.2015.12.010

73. Khan, A., Ahmed, T., Rizwan, M., Khan, N. Comparative therapeutic efficacy of Phyllanthus emblica (Amla) fruit extract and procaine penicillin in the treatment of subclinical mastitis in dairy buffaloes. Microb. Pathog., 2018; 115: 8-11. https://doi.org/10.1016/j. micpath.2017.12.038

74. Al-Samman AM, Siddique NA. Gas ChromatographyMass Spectrometry (GC-MS/MS) Analysis, Ultrasonic Assisted Extraction, Antibacterial and Antifungal Activity of Emblica officinalis Fruit Extract. Pharmacognosy Journal, 2019; 11(2): 315-323. https:// doi.org/10.5530/pj.2019.11.47

75. Lokanadhan, G., Dass, R. S., Kalagatur, N. K. Phytofabrication of Selenium Nanoparticles from Emblica officinalis fruit extract and exploring its biopotential applications: Antioxidant, Antimicrobial, and Biocompatibility. Front. Microbiol., 2019; 10: 931. https://doi.org/10.3389/fmicb.2019.00931

76. Punjabi K, Chitalia VK, Mukadam T, Sharma J, Maniar J, Vasave S, Vaidya S, Mao LD. Evaluation of the antimicrobial activity of gooseberry and wild apple fruit juices of the northeast region of India. $J$. Med. Herbs Ethnomed., 2017; 19: 1-7. https://doi. org/10.19071/jmhe.2017.v3.3160

77. Mayachiew P, Devahastin S. Antimicrobial and antioxidant activities of Indian gooseberry and galangal 
extracts. LWT-Food Sci. Technol., 2008; 41(7): 11531159. https://doi.org/10.1016/j.lwt.2007.07.019

78. Dhale DA, Mogle UP. Phytochemical screening and antibacterial activity of Phyllanthus emblica (L.). Sci. Res. Reporter., 2011; 1(3): 138-142.

79. Gao, Q., Li, X., Huang, H., Guan, Y., Mi, Q., Yao, J. (2018). The Efficacy of a Chewing Gum Containing Phyllanthus emblica Fruit Extract in Improving Oral Health. Current Microbiology, 75(5), 604-610. https:// doi.org/10.1007/s00284-017-1423-7

80. Saxena R, Patil P. In vitro antibacterial activity of Emblica officinalis essential oil against Staphylococcus aureus. Int. J. Theor. Appl. Sci., 2014; 6(2): 7-9.

81. Ahmed WA, Nadhom BN, Abdulrazaq NA. Comparative study for the antibacterial activity of the Amla (Emblica officinalis) phenolic extract and some antibiotics against four pathogenic bacteria In vitro. J. Microb. Biochem. Technol., 2016; 8: 48

82. Rahman, M., Rahman, M.M., Deb, S.C., Alam, M.S., Alam, M.J., \& Islam, M.T. Molecular identification of multiple antibiotic resistant fish pathogenic Enterococcus faecalis and their control by medicinal herbs. Sci Rep., 2017; 7(1), 3747. https://doi. org/10.1038/s41598-017-03673-1

83. Shrestha AK, Tiwari RD. Antifungal activity of crude extracts of some medicinal plants against Fusarium solani (Mart.) Sacc. Ecoprint: Int. J. Ecol., 2009; 16: 75-78. https://doi.org/10.3126/eco.v16i0.3476

84. Satish S, Mohana DC, Raghavendra MP, Raveesha KA. Antifungal activity of some plant extracts against important seed borne pathogens of Aspergillus sp. J. Agri. Tech., 2007; 3(1): 109-119.

85. Bobbarala V, Katikala PK, Naidu KC, Penumajji S. Antifungal activity of selected plant extracts against phytopathogenic fungi Aspergillus niger F2723. Indian J. Sci. Technol., 2009; 2(4): 87-90.

86. Vijayalakshmi S, Arunkumar V, Anju D, Gunasundari P, Moorthy P, Chandrasekharan AK. Comparative antimicrobial activities of Emblica officinalis and Ocimum sanctum. Anc. Sci. Life, 2007; 27(2): 1-6.

87. Thaweboon B, Thaweboon S. Effect of Phyllanthus emblica Linn. on Candida adhesion to oral epithelium and denture acrylic. Asian Pac. J. Trop. Med., 2011; 4(1): 41-45. https://doi.org/10.1016/S19957645(11)60029-1

88. Potdar S, Lakshminarayan N, Goud RS. Antimicrobial efficacy of Emblica officinalis fruit extracts on $S$. mutans, E. faecalis and C. albicans. Adv. Hum. Biol., 2014; 4(1): 26-30.

89. Sukanya MK, Suku S, Aruna SR. Phytochemical analysis, antimicrobial screening and antihelminthic properties of Phyllanthus emblica. Int. J. Pharm. Biol. Sci., 2013; 4(4): 55-64.

90. Aneja KR, Joshi R, Sharma C. In vitro antimicrobial activity of Sapindus mukorossi and Emblica officinalis against dental caries pathogens. Ethnobotan Leaflets, 2010; 14: 402-412

91. Gautam AK, Avasthi S, Sharma A, Bhadauria R. Antifungal potential of triphala churna ingredients against Aspergillus species associated with them during storage. Pak. J. Biol. Sci., 2012; 15(5): 244-249. https://doi.org/10.3923/pjbs.2012.244.249

92. Nath A, Raghunatha P, Joshi SR. Diversity and biological activities of endophytic fungi of Emblica officinalis, an ethnomedicinal plant of India. Mycobiology, 2012; 40(1): 8-13. https://doi.org/10.5941/ MYCO.2012.40.1.008

93. Chugh CA, Bharti D. Chemical characterization of antifungal constituents of Emblica officinalis. Allelopathy J., 2014; 34(1): 155-178.

94. Dharajiya D, Khatrani T, Patel P, Moitra N. Evaluation of antifungal activity of Emblica officinalis, Aloe vera and Vitex negundo extracts. J. Chem. Biol. Phys. Sci., 2015; 5(4): 3990-3996.

95. Wang YF, Wang XY, Ren Z, Qian CW, Li YC, Kaio K, Wang $\mathrm{QD}$, Zhang $\mathrm{Y}$, Zheng LY, Jiang JH, Yang CR. Phyllaemblicin $B$ inhibits Coxsackie virus B3 induced apoptosis and myocarditis. Antiviral Res., 2009; 84(2): 150-158. https://doi.org/10.1016/j.antiviral.2009.08.004

96. Xiang Y, Pei Y, Qu C, Lai Z, Ren Z, Yang K, Xiong S, Zhang Y, Yang $C$, Wang $D$, Liu $Q$. In vitro anti-herpes simplex virus activity of 1,2,4,6-tetra-O-galloyl-b-D-glucose from Phyllanthus emblica L. (Euphorbiaceae). Phytother. Res., 2011; 25(7): 975-982. https://doi.org/10.1002/ ptr.3368

97. Liu $G$, Xiong $S$, Xiang YF, Guo CW, Ge F, Yang CR, Zhang YJ, Wang YF, Kitazato K. Antiviral activity and possible mechanisms of action of pentagalloyl-glucose (PGG) against influenza A virus. Arch. Virol., 2011; 156(8): 1359-1369. https://doi.org/10.1007/s00705-0110989-9

98. Vermani K, Garg S. Herbal medicines for sexually transmitted diseases and AIDS. J. Ethnopharmacol., 2002; 80(1): 49-66. https://doi.org/10.1016/S03788741(02)00009-0

99. Estari M, Venkanna L, Sripriya D, Lalitha R. Human Immunodeficiency Virus (HIV-1) reverse transcriptase inhibitory activity of Phyllanthus emblica plant extract. Biol. Med., 2012; 4(4): 178-182.

100. Mahata S, Pandey A, Shukla S, Tyagi A, Husain SA, Das BC, Bharti AC. Anticancer activity of Phyllanthus emblica Linn. (Indian gooseberry): Inhibition of transcription factor AP-1 and HPV gene expression in cervical cancer cells. Nutr. Cancer, 2013; 65(1): 88-97. https://doi.org/10.1080/01635581.2013.785008

101. Tewari, R., Kumar, V. \& Sharma, H.K. Physical and chemical characteristics of different cultivars of Indian gooseberry (Emblica officinalis). J. Food Sci. Technol., 2019; 56(3): 1641-1648. https://doi.org/10.1007/ s13197-019-03595-y

102. Cowan MM. Plant products as antimicrobial agents. Clin Microbiol Rev, 1999; 12(4): 564-582. https://doi. org/10.1128/CMR.12.4.564

103. Ramkumar KM, Rajaguru P, Ananthan R. Antimicrobial properties and phytochemical constituents of an antidiabetic plant Gymnema montanum. Adv. Biol. Res., 2007; 1(1-2): 67-71.

104. Elangovan M, Dhanarajan MS, Elangovan I. Determination of bioactive compounds from the Petroleum ether leaf extract of Moringa oleifera and Phyllanthus emblica using GC-MS analysis. W. J. Pharm. Res., 2015; 4(3): 1284-1298.

105. Liu X, Zhao M, Luo W, Yang B, Jiang Y. Identification 
of volatile components in Phyllanthus emblica L. and their antimicrobial activity. J. Med. Food, 2009; 12(2): 423-428. https://doi.org/10.1089/jmf.2007.0679

106. Mahesh B, Satish S. Antimicrobial activity of some important medicinal plant against plant and human pathogens. W. J. Agric. Sci., 2008; 4(5): 839-843.

107. Sharma S, Bharose R, Agarawal SK, Pal K. Antibacterial activities against different selective MIC extraction of Amla. Int. J. Pharm. Profess Res., 2012; 3(3): 587-591.

108. Kumari P, Khatkar BS. Assessment of total polyphenols, antioxidants and antimicrobial properties of aonla varieties. J. Food Sci. Technol., 2016; 53(7): 3093-3103. https://doi.org/10.1007/s13197-016-2282-0

109. Ganguly DK. Tea consumption on oxidative damage and cancer. Indian Counc. Med. Res. Bull., 2003; 33: 37-51.

110. Stainer R, Adelberg EA, Ingraham J. 1987. In general microbiology, pp. 619-621. 4th Ed. Mac Millan Publisher Ltd, NewYork.

111. Fyhrquish P, Mwasumbi L, Haeggstrom C, Vuorela $\mathrm{H}$. Antifungal activity of selected spp. of Terminalia collected in Tanzania. Pharm. Biol, 2004; 42: 308-317. https://doi.org/10.1080/13880200490511891

112. Agoramoorthy G, Ghandrasekaran M, Venkatesalu V. Antibacterial and antifungal activities of fatty acid methyl esters of the blind of your eye mangrove from India. Braz. J. Microbiol., 2007; 38(4): 739-742. https:// doi.org/10.1590/S1517-83822007000400028

113. Negi PS. Plant extracts for the control of bacterial growth: Efficacy, stability and safety issues for food application. Int. J. Food Microbiol., 2012; 156(1): 7-17. https://doi.org/10.1016/j.ijfoodmicro.2012.03.006

114. Davidson PM. Chemical preservatives and natural antimicrobial compounds, 2001; pp. 593-627. In Doyle MP, Beuchat LR, Montville TJ (eds). Food Microbiology: Fundamental and Frontiers. Washington, DC. ASM Press.

115. Hammer KA, Carson CF, Riley TV. Antimicrobial activity of essential oils and other plant extracts. J. Appl. Microbiol., 1999; 86(6): 985-990. https://doi. org/10.1046/j.1365-2672.1999.00780.x

116. Essawi T, Srour M. Screening of some Palestinian medicinal plants for antibacterial activity. J. Ethnopharmacol., 2000; 70(3): 343-349. https://doi. org/10.1016/S0378-8741(99)00187-7

117. Tim P, Andrew L. Antimicrobial activity of flavonoids. Int. J. Antimicrob. Agents, 2005; 26(5): 343-356. https:// doi.org/10.1016/j.ijantimicag.2005.09.002

118. Sawant L, Prabhakar B, Pandita N. Quantitative HPLC analysis of ascorbic acid and gallic acid in Phyllanthus emblica. J. Anal. Bioanal. Tech., 2012; 1(111): 1-4. https://doi.org/10.4172/2155-9872.1000111

119. Dasaroju S, Gottumukkala KM. Current trends in the research of Emblica officinalis (Amla): A pharmacological perspective. Int. J. Pharm. Sci. Rev. Res., 2014; 24: 150-159.

120. Dharmananda S. EmblicMyrobalans: AMLA Key Herb of Ayurvedic Medicine. ITM; 2003.

121. Habib-ur-Rehman, Yasin KA, Choudhary MA, Khaliq N, Atta-Ur-Rahman, Choudhary MI, Malik S. Studies on the chemical constituents of Phyllanthus emblica. Natl. Prod. Res., 2007; 21(9): 775-781. https://doi. org/10.1080/14786410601124664

122. Xu HX, Lee SF. Activity of plant flavonoids against antibiotic resistant bacteria. Phytother. Res., 2001; 15(1): 39-43. https://doi.org/10.1002/10991573(200102)15:1\%3C39::AID-PTR684\%3E3.0.CO;2-R

123. Shohaib T, Shafique $M$, Dhanya N, Divakar M. Importance of flavonoids in therapeutics. Hygeia. J. D. Med., 2011; 3(1): 1-18.

124. Ahmad I, Beg AZ. Antimicrobial and phytochemical studies on 45 Indian medicinal plants against multidrug resistant human pathogens. J. Ethnopharmacol., 2001; 74(2): 113-123. https://doi.org/10.1016/S03788741(00)00335-4

125. Shende K, Singh N, Negi P. Phytochemical characterization and biological activities of Docynia indica (Wall) fruit extracts. J. Mol. Genet. Med., 2016; 10(204): 1-5.

126. Beceiro A, Tomas M, Bou G. Antimicrobial resistance and virulence: A successful or deleterious association in the bacterial world? Clin. Microbiol. Rev., 2013; 26(2): 185-230. https://doi.org/10.1128/CMR.0005912

127. Masum MM, Siddiqa MM, Ali KA, Zhang $Y$, Abdallah Y, Ibrahim E, Qiu W, Yan C, Li B. Biogenic Synthesis of Silver Nanoparticles Using Phyllanthus emblica Fruit Extract and Its Inhibitory Action Against the Pathogen Acidovorax oryzae Strain RS-2 of Rice Bacterial Brown Stripe. Front. Microbiol., 2019; 10: 820. https://doi. org/10.3389/fmicb.2019.00820

128. Nayagam V, Gabriel M, Palanisamy K. Green synthesis of silver nanoparticles mediated by Coccinia grandis and Phyllanthus emblica: A comparative comprehension. Appl. Nanosci., 2018; 8(3): 205-219. https://doi.org/10.1007/s13204-018-0739-3

129. Shah PJ, Malik R. Study of antibacterial activity of Phyllanthus emblica and its role in green synthesis of silver nanoparticles. J. Drug Deliv. Ther., 2019; 9(3): 76-81.

130. Kim JS, Kuk E, Yu KN, Kim JH, Park SJ, Lee HJ, Kim SH, Park YK, Park YH, Hwang CY, Kim YK, Lee YS, Jeong DH, Cho $\mathrm{MH}$. Antimicrobial effects of silver nanoparticles. Nanomedicine, 2007; 3(1): 95-101. https://doi. org/10.1016/j.nano.2006.12.001

131. Oves M, Khan MS, Zaidi A, Ahmed AS, Ahmed F, Ahmad E, Sherwani A, Owais M, Azam A. Antibacterial and cytotoxic efficacy of extracellular silver nanoparticles biofabricated from chromium reducing novel OS4 strain of Stenotrophomonas maltophilia. PLoS One, 2013; 8(3): e59140. https://doi.org/10.1371/journal. pone.0059140

132. Aziz N, Pandey R, Barman I, Prasad R. Leveraging the attributes of Mucor hiemalis-derived silver nanoparticles for a synergistic broad-spectrum antimicrobial platform. Front. Microbiol., 2016; 7: 1984. https://doi.org/10.3389/fmicb.2016.01984

133. Mahmoud WM, Abdelmoneim TS, Elazzazy AM. The impact of silver nanoparticles produced by Bacillus pumilus as antimicrobial and nematicide. Front. Microbiol., 2016; 7: 1746. https://doi.org/10.3389/ fmicb.2016.01746

134. Elbeshehy, EK, Elazzazy, AM, \& Aggelis, G. Silver nanoparticles synthesis mediated by new isolates of 
Bacillus spp., nanoparticle characterization and their activity against Bean Yellow Mosaic Virus and human pathogens. Front. Microbiol., 2015; 6: 453. https://doi. org/10.3389/fmicb.2015.00453

135. Oves M, Aslam M, Rauf MA, Qayyum S, Qari HA Khan MS, Alam MZ, Tabrez S, Pugazhendhi A, Ismail IMI. Antimicrobial and anticancer activities of silver nanoparticles synthesized from the root hair extract of Phoenix dactylifera. Mater. Sci. Eng. C., 2018; 89: 429-443. https://doi.org/10.1016/j.msec.2018.03.035

136. Aziz N, Sherwani A, Faraz M, Fatma T, Prasad R. Illuminating the anticancerous efficacy of a new fungal chassis for silver nanoparticle synthesis. Front. Chem., 2019; 7: 65. https://doi.org/10.3389/ fchem.2019.00065

137. Manikandan R, Beulaja M, Thiagarajan R, Palanisamy S, Goutham G, Koodalingam A, Prabhu NM, Kannapiran E, JothiBasu M, Arulvasu C, Arumugam M. Biosynthesis of silver nanoparticles using aqueous extract of Phyllanthus acidus L. fruits and characterization of its anti-inflammatory effect against $\mathrm{H}_{2} \mathrm{O}_{2}$ exposed rat peritoneal macrophages. Proc. Biochem., 2017; 55: 172181. https://doi.org/10.1016/j.procbio.2017.01.023

138. Dinesh M, Roopan SM, Selvaraj $\mathrm{Cl}$, Arunachalam P. Phyllanthus emblica seed extract mediated synthesis of PdNPs against antibacterial, heamolytic and cytotoxic studies. J. Photochem. Photobiol. B: Biol., 2017; 167: 64-71. https://doi.org/10.1016/j. jphotobiol.2016.12.012

139. Anbukkarasi V, Srinivasan R, Elangovan N. Antimicrobial activity of green synthesized zinc oxide nanoparticles from Emblica officinalis. Int. J. Pharm. Sci. Rev. Res., 2015; 33(2): 110-115.

140. Arbade, G. K., Kumar, V., Tripathi, V., Menon, A., Bose, S., Patro, T. U. Emblica officinalis-loaded poly (I-caprolactone) electrospun nanofiber scaffold as potential antibacterial and anticancer deployable patch. New J. Chem., 2019; 43(19), 7427-7440. https:// doi.org/10.1039/C9NJ01137D

141. Yokozawa T, Kim HY, Kim HJ, Okubo T, Chu DC, Juneja LR. Amla (Emblica officinalis Gaertn.) prevents dyslipidaemia and oxidative stress in the ageing process. British J. Nutr., 2007; 97(6): 1187-1195. https://doi.org/10.1017/S0007114507691971

142. Muthuraman A, Sood S, Singla SK. The antiinflammatory potential of phenolic compounds from Emblica officinalis L. in rat. Inflammopharmacology, 2011; 19(6): 327-334. https://doi.org/10.1007/s10787-0100041-9

143. Yatoo MI, Gopalakrishnan A, Saxena A, Parray OR, Tufani NA, Chakraborty S, Tiwari R, Dhama K, Iqbal HMN. Anti-Inflammatory Drugs and Herbs with Special Emphasis on Herbal Medicines for Countering Inflammatory Diseases and Disorders - A Review. Recent Pat. Inflamm. Allergy Drug Discov., 2018; 12(1):39-58. https://doi.org/10.2174/187221 3X12666180115153635

144. Prakash D, Upadhyay G, Gupta C, Pushpangadan P, Singh KK. Antioxidant and free radical scavenging activities of some promising wild edible fruits. Int Food Res J, 2012; 19(3): 1109-1116.

145. Gupta, P., Parminder, N. and Jaspreet, S. Antimicrobial and Antioxidant activity on Emblica officinalis seed extract. Int. J. Res. Ayurveda Pharm., 2012; 3(4), 591-596.

146. Chaieb I. Saponins as insecticides: a review. Tunisian J. Plant. Prot., 2010; 5(1): 39-50.

147. Murugan K, Madhiyazhagan P, Nareshkumar A, nataraj T, Dinesh D, Hwang JS, Nicoletti M. Mosquitocidal and water purification properties of Ocimum sanctum and Phyllanthus emblica. J. Entomol. Acarolog. Res., 2012; 44(17): 90-97. https://doi.org/10.4081/jear.2012.e17

148. Pemminati S, Gopalkrishana HN, Shenoy AK, Sahu SS, Mishra S, Meti V, Vinod N. Antidepressant activity of aqueous extract of fruits of Emblica officinalis in mice. Int. J. App. Biol. Pharm. Technol., 2010; 1(2): 449-454.

149. Jaijoy K, Soonthornchareonnon N, Panthong A, Sireeratawong S. Anti-inflammatory and analgesic activities of the water extract from the fruit of Phyllanthus emblica Linn. Int. J. Appl. Res. Nat. Prod., 2010; 3(2): 28-35.

150. Singh I, Sharma A, Jindal A, Soyal D, Goyal PK. Protective effect of Emblica officinalis fruit extract against gamma irradiation in mice. Pharmacology Online, 2006, 2: 128-150.

151. Santoshkumar J, Manjunath S, Sakhare PM. A study of antihyperlipedemia, hypolipedemic and antiatherogenic activity of fruit of Emblica officinalis (amla) in high fat fed Albino rats. Int. J. Med. Res. Health Sci., 2013; 2(1): 70-77.

152. Qureshi SA, Asad W, Sultana V. The effect of Phyllanthus emblica Linn on type - II diabetes, triglycerides and liver-specific enzyme. Pak. J. Nutr., 2009; 8(2): 125-128. https://doi.org/10.3923/pjn.2009.125.128

153. Brochot, A., Azalbert, V., Landrier, J. F., Tourniaire, F., Serino, M. A 2-week Treatment with Plant Extracts Changes Gut Microbiota, Caecum Metabolome and Markers of Lipid Metabolism in ob/ob Mice. Mol. Nutr. Food Res., 2019; 1900403. https://doi.org/10.1002/ mnfr.201900403

154. Husain I, Zameer S, Madaan T, Minhaj A, Ahmad W, Iqubaal A, Ali A, Najmi AK. Exploring the multifaceted neuroprotective actions of Emblica officinalis (Amla): A review. Metab. Brain Dis., 2019; 1-9. https://doi. org/10.1007/s11011-019-00400-9

155. Baliga MS, Shivashankara AR, Thilakchand KR, BaligaRao MP, Palatty PL, George T, Rao S. Hepatoprotective effects of the Indian gooseberry (Emblica officinalis Gaertn): A revisit, 2019; pp. 193-201. In Dietary Interventions in Liver Disease, Academic Press. https:// doi.org/10.1016/B978-0-12-814466-4.00016-1

156. Choudhary M, Grover K. Amla (Emblica officinalis L.) Oil. In Fruit Oils: Chemistry and Functionality, 2019; 875882. Springer, Cham. https://doi.org/10.1007/978-3030-12473-1_48

157. Baratta MT, Dorman HD, Deans SG, Figueiredo AC, Barroso JG, Ruberto G. Antimicrobial and antioxidant properties of some commercial essential oils. Flav. Fragr. J., 1998; 13(4): 235-244. https://doi.org/10.1002/ (SICI)1099-1026(1998070)13:4\%3C235::AIDFFJ733\%3E3.3.CO;2-K

158. Yang B, Liu P. Composition and biological activities of hydrolyzable tannins of fruits of Phyllanthus emblica. J. Agric. Food Chem., 2014; 62(3): 529-541. https:// 
doi.org/10.1021/jf404703k

159. Khan MS, Qais FA, Ahmad I. Indian berries and their active compounds: Therapeutic potential in cancer prevention, 2019; pp. 179-201. In New Look to Phytomedicine. Academic Press. https://doi. org/10.1016/B978-0-12-814619-4.00008-2

160. Bagavan A, Rahuman AA, Kamaraj C, Kaushik NK, Mohanakrishnan D, Sahal D. Antiplasmodial activity of botanical extracts against Plasmodium falciparum. Parasitol. Res., 2011; 108(5): 1099-1109. https://doi. org/10.1007/s00436-010-2151-0

161. Pinmai K, Hiriote W, Soonthornchareonnon N, Jongsakul K, Sireeratawong S, Tor-Udom S. In vitro and in vivo antiplasmodial activity and cytotoxicity of water extracts of Phyllanthus emblica, Terminalia chebula, and Terminalia bellerica. J. Med. Assoc. Thai., 2011; 93(12): 120.

162. Sharma, R, Martins, N, Kuca, K, Chaudhary, A, Kabra, A, Rao, MM, Prajapati, PK. Chyawanprash: A Traditional Indian Bioactive Health Supplement. Biomolecules, 2019; 9(5): 161. https://doi.org/10.3390/biom9050161

163. Dhama, K, Chakraborty, S, Tiwari, R, Verma, AK, Saminathan, M, Amarpal, Yashpal S Malik, Zahra Nikousefat, Moosa Javdani, Khan, RU. A concept paper on novel technologies boosting production and safeguarding health of humans and animals. Res. Opin. Anim. Vet. Sci., 2014; 4(7): 353-370.

164. Abd El-Hack ME, Alagawany M, Farag MR, Arif M, Emam M, Dhama K, Sarwar M, Sayab M. Nutritional and pharmaceutical applications of nanotechnology: Trends and advances. Int. J. Pharmacology, 2017; 13(4): 340-350. https://doi.org/10.3923/ijp.2017.340.350

165. Prasad, M., Lambe UP, Brar B, Shah I, Manimegalai J,
Ranjan K, Rao R, Kumar S, Mahant S, Khurana SK, Iqbal HMN, Dhama, K, Misri J, Prasad G. Nanotherapeutics: An insight into healthcare and multi-dimensional applications in medical sector of the modern world. Biomed Pharmacother., 2018; 97: 1521-1537. https:// doi.org/10.1016/j.biopha.2017.11.026

166. Munjal A, Khandia R, Dhama K, Sachan S, Karthik K, Tiwari R, Malik YS, Kumar D, Singh RK, Iqbal HMN, Joshi SK.(2017). Advances in Developing Therapies to Combat Zika Virus: Current Knowledge and Future Perspectives. Front Microbiol., 8: 1469. https://doi. org/10.3389/fmicb.2017.01469

167. Ramees TP, Dhama K, Karthik K, Rathore RS, Kumar A, Saminathan M, Tiwari R, Malik YS, Singh RK. Arcobacter: an emerging food-borne zoonotic pathogen, its public health concerns and advances in diagnosis and control - a comprehensive review. Vet. Quarterly, 2017; 37(1): 136-161. https://doi.org/10.1 080/01652176.2017.1323355

168. Dhama K, Karthik K, Khandia R, Chakraborty S, Munjal A, Latheef SK, Kumar D, Ramakrishnan MA, Malik YS, Singh R, Malik SVS, Singh RK, Chaicumpa W. Advances in Designing and Developing Vaccines, Drugs, and Therapies to Counter Ebola Virus. Front. Immunol., 2018; 9: 1803. https://doi.org/10.3389/ fimmu.2018.01803

169. Singh RK, Dhama K, Chakraborty S, Tiwari R, Natesan S, Khandia R, Munjal A, Vora KS, Latheef SK, Karthik K, Singh Malik Y, Singh R, Chaicumpa W, Mourya DT. Nipah virus: epidemiology, pathology, immunobiology and advances in diagnosis, vaccine designing and control strategies - a comprehensive review. Vet. Quarterly, 2019; 39(1): 26-55. https://doi.org/10.1080/016521 76.2019 .1580827 